\title{
Alpaca liveweight variations and fiber production in Mediterranean range of Chile
}

\author{
GIORgIO CASTELLARO G., JORGE GARCIA-HUIDOBRO P. DE A., AND PEDRO SALINAS
}

Authors are researchers of the Agroecology Program, Instituto de Investigaciones Agropecuarias (INIA), La Platina Experimental Station, Casilla 439-3, Santiago, Chile.

\begin{abstract}
A study of liveweight changes of alpaca adult males, females, and their progeny, was conducted through 3 seasons under continuous grazing on natural grasslands on the Mediterranean range of the Chilean Central Zone. Liveweight changes were positive and highest in spring (100 to $200 \mathrm{~g}$ day $\left.^{-1}\right)$, moderate during winter ( 50 to $\left.100 \mathrm{~g} \mathrm{day}^{-1}\right)$, and negative only at the end of summer

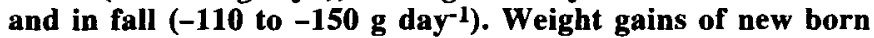
alpacas were greatest $\left(110\right.$ to $\left.150 \mathrm{~g} \mathrm{day}^{-1}\right)$ in the first 90 days after birth and then decreased slightly, reaching values of $75 \mathrm{~g} \mathrm{day}^{-1}$ at 8.5 months old. Weight gains stabilized at 10 to $20 \mathrm{~g}^{\text {day-1 }}$ at $3-^{3}$ years of age. The average annual fibre production was 1.57 and $2.36 \mathrm{~kg}$ in females and males, respectively; staple length varied between 8 and $10 \mathrm{~cm}$.
\end{abstract}

Key Words: South American Camelids, fiber production

Alpaca (Lama pacos Linn.) is a domestic species found in the Altiplanic ecosystems of Peru, Bolivia, Argentina, and Chile (Fowler 1989). In Chile, alpacas are distributed mainly over the Altiplanic Chilean Zone of Tarapaca, with an estimated population of 32,00 animals. Alpacas develop in cold, dry highland environments. Their diet is based exclusively on natural flood grasslands ("bofedales") and drylands ("pajonales" and "tolares"), the former being much more important. The alpaca is a specialized feeder with restricted habitat (De Carolis 1987). The specialization in habitat and diet could imply a low adaptability to different environmental, feeding, and management conditions. However, preliminary evaluations showed alpacas to be well adapted to different conditions (Crossley et al. 1990), and maintained suitable growth and productivity (Castellaro and GarcíaHuidobro 1991). This species represents an important genetic resource and potential alternative of fiber production for marginal areas, not only in the Altiplanic Zone, but also in rangelands of the Chilean Mediterranean Central Zone. This study was conducted to determine alpacas' liveweight gain and fiber production on rangeland of the Chilean Central Zone.

\section{Study Area}

This study was conducted at the Hidango Experimental Substation (Lat. 34 $7^{\circ} \mathrm{S}$; Long. $71^{\circ} 44^{\prime} \mathrm{W}$; elevation $304 \mathrm{~m}$ ).

Research was funded by Fundacion Andes.

Manuscript accepted 8 Mar. 1998.

\section{Resumen}

Durante tres temporadas, se efectuó un estudio orientado a evaluar los cambios de peso vivo de alpalcas adultas, machos y hembras, como también su progenie, que pastorearon continuamente una pradera natural la zona mediterránea central de Chile. Los cambios de peso vivo fueron positivos y más altos durante la primavera (100 a $\left.200 \mathrm{~g} \mathrm{día}^{-1}\right)$, moderados durante el invierno ( 50 a $100 \mathrm{~g} \mathrm{día}^{-1}$ ), siendo negativos solamente al final del verano y en el otoño ( -100 a $\left.-150 \mathrm{~g} \mathrm{dia}^{-1}\right)$. Las mayores ganancias de peso de las crías de alpacas (110 a $\left.150 \mathrm{~g} \mathrm{día}^{-1}\right)$ se obtuvieron en los primeros 90 días después del nacimiento, decreciendo paulatinamente hasta alcanzar valores de $75 \mathrm{~g}_{\text {día-1 a }}$ los 8.5 meses de edad. Las ganancias de peso se estabilizaron con valores entre 10 a $20 \mathrm{~g}_{\text {día-1 }}$ a los tres años de edad. La producción anual promedio de fibra fue de 1.57 y $2.36 \mathrm{~kg}$ in hembras y machos, respectivamente; la longitud de la mecha varió entre 8 y $10 \mathrm{~cm}$.

Soils are classified as Typic Palexeralfs (Soil Survey Staff 1990). Average annual precipitation is $890 \mathrm{~mm}$ concentrated in winter; annual potential evapotranspiration is $1,330 \mathrm{~mm}$. June is the coldest month, and February the warmest; mean monthly temperatures are $5.4^{\circ}$ and $24.7^{\circ}$, respectively (Santibáñez and Uribe 1990). Average monthly precipitation and temperature during the experimental period are shown in Figure 1. Vegetation at the study site corresponds to a "pseudo-savanna" with a dominance of brushwood "espino" (Acacia caven Mol. ) and a total canopy cover of 3 to $50 \%$. Herbage is comprised mainly of annual grasses and forbs (Table 1). Perennial Piptochaetium, Stipa, and Danthonia grass species are found on severely eroded sites (Castellaro and García-Huidobro 1991). Estimated metabolizable energy and crude protein concentration in forage vary from 4.8 to $9.3 \mathrm{Mj} \mathrm{kg}^{-1}$ and from 7.1 to $21.0 \%$, respectively (Table 2). The available standing crop of herbage, from June 1990 until January 1993 is presented in Figure 2 (Squella, unpublished).

\section{Material and Methods}

Study animals were 23 young adult females ( $3-5$ years old), 11 young males (3-4 years old), and 8 young females (less than 1 year old). According to their characteristics, the study animals were the "Huacaya" breed of alpacas (Calle 1982). Animals were collected from different areas of the Alitplanic Zone. Females grazed an area of 20 ha (1.55 alpacas ha- ${ }^{-1}$ ) and males grazed plots of 3.5 ha ( 3.14 alpacas $\left.\mathrm{ha}^{-1}\right)$. None of the animals received sup- 


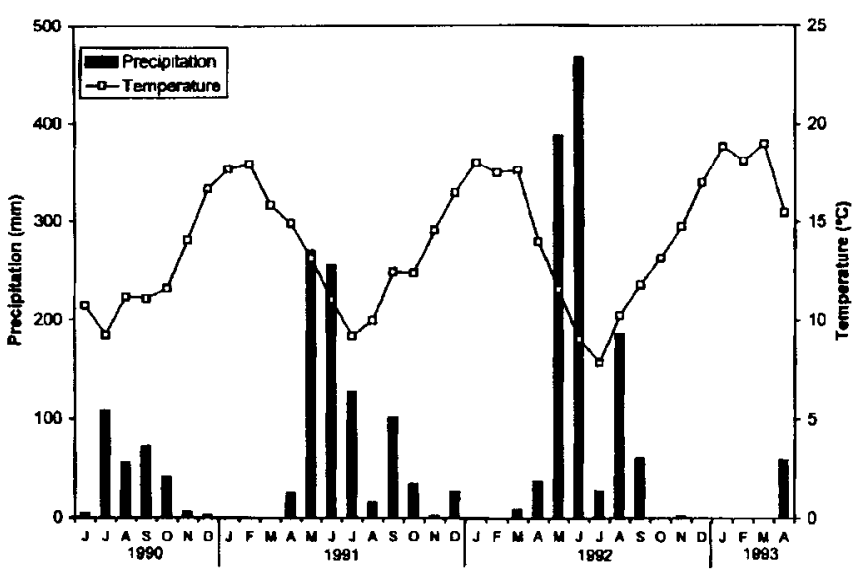

Fig. 1. Average monthly precipitation and temperature during experimental period.

plemental mineral or forage; thus, their diet was provided almost exclusively from forage. Liveweights $(\mathrm{kg})$ of all animals were determined every month, from 18 June 1990 until the end of the trial on 18 April 1993. Liveweight changes ( $\mathrm{g} \mathrm{day}^{-1}$ ) were estimated monthly, according to the following equation:

$$
\Delta \mathrm{LW}=\left(\mathrm{LW}_{\mathrm{i}+1}-\mathrm{LW}_{\mathrm{i}}\right) / \Delta \mathrm{t}
$$

with $\mathbf{L W}$, the average liveweight of females or males in month $i$ $+I$ and $i$, respectively, and $\Delta t$, a period of approximately 30 days. During the 33 months of study, birth weights and liveweights of the newborn were recorded monthly and used to develop an age-growth curve. Progeny were kept with their mothers during the study period. Shearing was mechanically done late in November 1990 and in October 1991 and 1992 by adding a "snowcomb" to a sheep fleecer. Fiber was classified and weighed separately for fleece (fiber covering the back, sides, and part of the neck) and other body fiber (fiber covering the abdomen, legs, and neck). Fiber staple length $(\mathrm{cm})$ was determined monthly, beginning in 1990, from the side (i.e., near the 6th rib) of each adult animal. To determine trends in weights of adult animals, a simple regression analysis was made, adjusting the weight according to age. After that, a Student Hypothesis Test was conducted to compare differences among means for weight and fiber parameter of equations (Steel and Torrie 1980). The annual fiber production

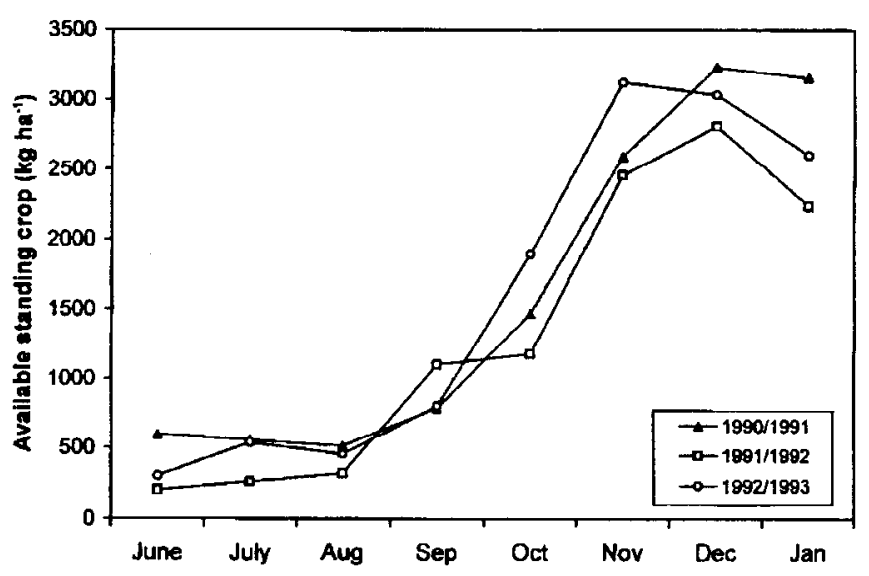

Fig. 2. Available herbage standing crop, 1990-1993.
Table 1. Study site herbaceous species composition (\%) by weight (from Castellaro and Garcia-Huidobro 1991)

\begin{tabular}{lc}
\hline \hline Plant Species & Composition \\
\hline Grasses and grasslike & \\
Avena barbata & 29.3 \\
Aira caryophyllea & 2.6 \\
Bromus berterianus & 5.7 \\
Bromus hordeaceus & 11.1 \\
Danthonia chilensis & 0.2 \\
Hordeum berteroanum & 13.8 \\
Lolium rigidum & 0.7 \\
Piptochaetium panicoides & 0.2 \\
P.stipoides & 1.0 \\
Stipa laevissima & 1.1 \\
Stipa manicata & 1.2 \\
Vulpia bromoides & 3.3 \\
Carex spp. & 0.3 \\
Other grasses and grasslikes & 3.6 \\
Total grasses and grasslikes & 74.1 \\
Forbs & \\
HyPochoeris glabra & 17.3 \\
Cynara cardunculus & 1.3 \\
Chaetanthera chilensis & 1.0 \\
Carthamus lanatus & 2.0 \\
Microseris pigmaea & 2.3 \\
Other forbs & 2.0 \\
Total forbs & 25.9 \\
\hline
\end{tabular}

(Y) was analyzed through Multifactor Analysis of Variance (Steel and Torrie 1980), considering YEAR and SEX, and their respective interaction, as the main factors and expressed by:

$$
Y_{i j k}=\mu+Y E A R_{i}+S E X_{j}+Y_{E A R}=S_{i} X_{j}+E_{i j k}
$$

Differences among means for total fiber production and percentage of fleece were compared using the Tukey Test. The growth curve for females was determined through the iterative adjusting method for nonlinear regression models (Marquardt 1963), having as parameters the birth weight (BW), mature weight (MW), and a growth coefficient (CGRO) according to the growth model for mammals proposed by Brody (1945), reported by Standing Committee on Agriculture (1990). All these analyses were carried out using STATGRAPHICS software ver. 5 (Coronado et al. 1994). All differences discussed were statistically significant at the $5 \%$ level unless otherwise indicated.

Table 2. Estimated study site herbage metabolizable energy and crude protein concentrations on dry matter basis (from Rodriguez and Squella 1987).

\begin{tabular}{lcc}
\hline Month & $\begin{array}{c}\text { Metabolized Energy } \\
\left(\mathrm{Mj} \mathrm{kg}^{-1}\right)\end{array}$ & $\begin{array}{c}\text { Crude Protein } \\
(\%)\end{array}$ \\
\hline May & 6.0 & 15.3 \\
June & 4.8 & 15.0 \\
July & 6.2 & 18.7 \\
August & 7.9 & 18.1 \\
Seplember & 7.7 & 21.0 \\
October & 9.3 & 14.7 \\
November & 6.5 & 11.3 \\
December & 7.9 & 9.5 \\
January & 7.4 & 9.5 \\
February & 7.8 & 7.1 \\
March & 7.8 & 8.2 \\
April & 6.9 & 11.8 \\
\hline Estimated metabolizable energy of dry matter=0.17 - DMD - 2: DMD= digestibility of
\end{tabular}

dry matter (\%), Standing Comittee on Agriculture (1990) 


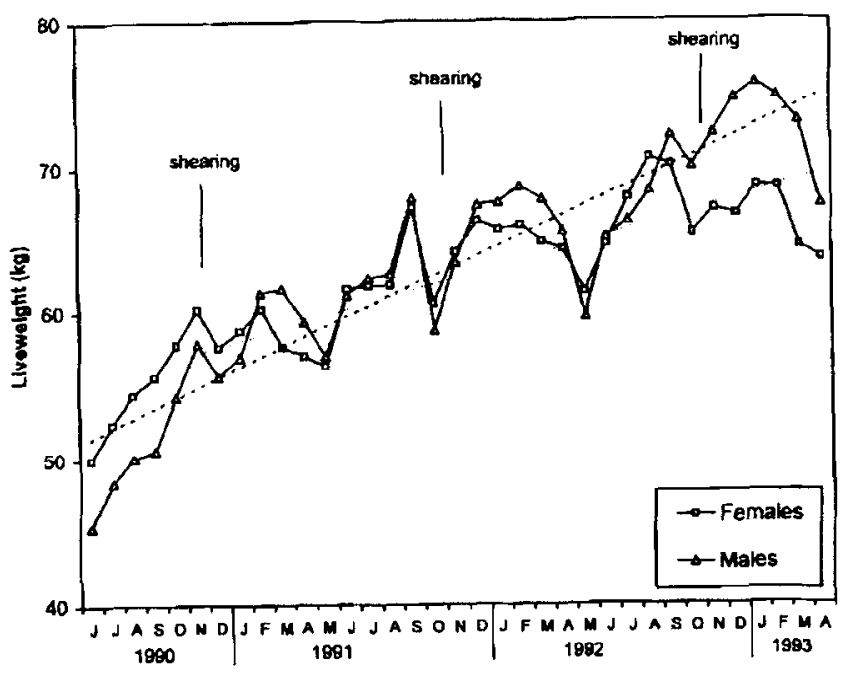

Fig. 3. Liveweight variation in alpaca flock, 1990-1993.

\section{Results and Discussion}

\section{Changes in liveweight of adult animals}

When the evaluation period started (June 1990) average liveweights were $45 \mathrm{~kg}$ for males and $50 \mathrm{~kg}$ for females (Fig. 3). During the study period females gained about half as much weight per day $\left(13.7 \mathrm{~g} \mathrm{day}^{-1}\right)$ as males $\left(22.4 \mathrm{~g}\right.$ day $\left.^{-1}\right)$. This implies that females and males continued growing until reaching the mature weight at about 6 years of age. At this age they had completed their full dental development and have reached their mature skeletal size (Calle 1982, Buztinza 1991). At the end of the evaluation period (April 1993), females stabilized their weights around $65 \mathrm{~kg}$ and males near $74 \mathrm{~kg}$ (Fig. 3). These values were higher than those reported on alpacas in the Altiplanic environment (Bustinza 1991), and similar to those reported by Davis et al. (1991), on Chilean alpacas managed with white clover-grass grassland, in New Zealand. During the evaluation period, alpacas gained or lost weight (Fig. 4.) mainly because of the monthly variations in nutritional contents of the grassland (Table 2) and

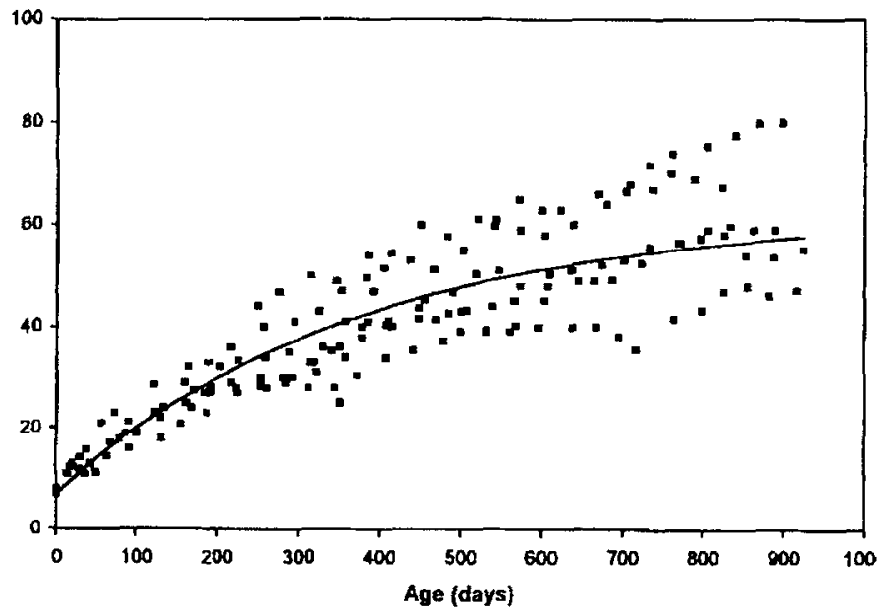

Fig. 5. Female growth curve according to age.

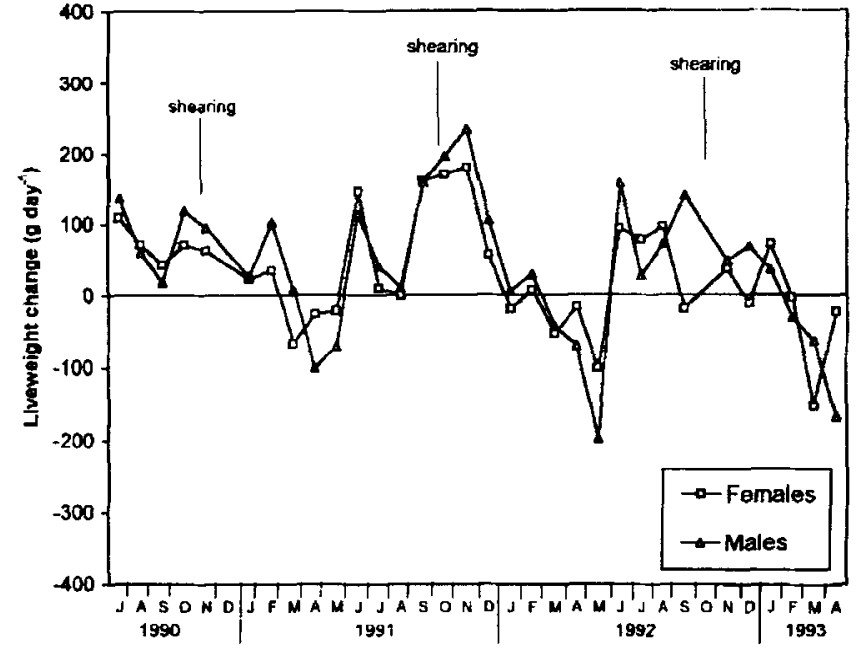

Fig. 4. Liveweight change in alpaca flock, 1990-1993.

because of shearing. In the winter period, liveweight gains were small, and decreased, reaching values near zero at the end of July. Then liveweight gains increased reaching their highest values in October; this coincides with the greatest rates of biomass increase of the grassland (Fig. 2) and its higher metabolizable energy and crude protein concentrations (Table 2). After October, liveweight gain began to decrease, being negative during the fall and the beginning of winter. Those last periods are critical, because of the lowest metabolizable energy concentrations in the forage (Table 2) and its capacity to supply maintenance requirements of the animals. According to San Martin (1991), for an alpaca of $62 \mathrm{~kg}$ of liveweight, forge intake should have concentrations near $7.74 \mathrm{Mj}$ $\mathrm{kg}^{-1}$ of metabolizable energy and $7.7 \%$ of crude protein to meet the maintenance requirements of animals.

\section{Female Growth Curve}

Liveweights of growing females, measured from birth to 900 days old, are shown in Figure 5. The growth model proposed by Brody (1945) and reported by the Standing Committee on

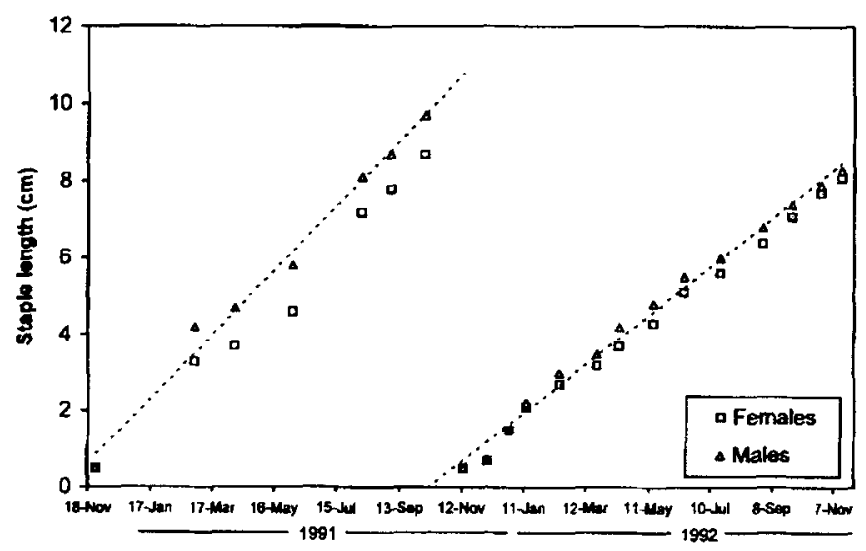

Fig. 6. Fiber length variation in alpacas, 1991-1992. 
Table 3. Mean ( \pm SE) annual fiber production and fleece percentage for females and male alpacas, 1990-1992.

\begin{tabular}{|c|c|c|c|c|c|c|}
\hline \multirow[b]{2}{*}{ Year } & \multicolumn{3}{|c|}{ Fleece } & \multicolumn{3}{|c|}{ Fleece percentage } \\
\hline & Females & Males & Mean & Females & Males & Mean \\
\hline & \multicolumn{3}{|c|}{$\ldots \ldots\left(\mathrm{kg}\right.$ animal $\left.{ }^{-1}\right) \ldots \ldots$} & \multicolumn{3}{|c|}{ (\%)- } \\
\hline 1991 & $1.28 \pm 0.10$ & $1.88 \pm 0.15$ & $1.46 \pm 0.08 b$ & $64.5 \pm 1.0$ & $70.3 \pm 2.2$ & $66.4 \pm 1.5 b$ \\
\hline 1992 & $1.81 \pm 0.09$ & $2.62 \pm 0.13$ & $2.08 \pm 0.10 \mathrm{a}$ & $65.6 \pm 1.3$ & $77.0 \pm 1.9$ & $69.4 \pm 1.5 b$ \\
\hline
\end{tabular}

${ }^{1}$ Mean for sex or year followed by same letter are not significantly different at the $5 \%$ level.

Agriculture (1990) explained $78 \%$ of the variation in liveweight. The estimated values ( \pm SE) for birth weight (BW), mature weight (MW), and the growth coefficient (CGRO) were:

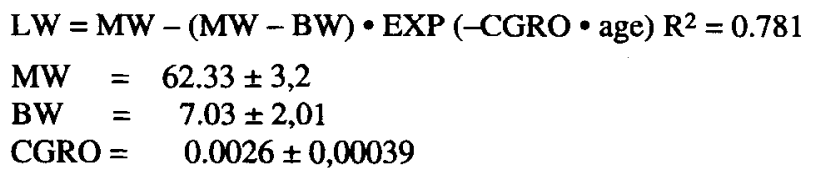

According to this equation, the estimated birth and mature weight are in concordance with the ranges cited by Bustinza (1991) and Calle (1982) for these variables. During the first 90 days since birth, females gain between $110-150 \mathrm{~g} \mathrm{day}^{-1}$, reaching an average liveweight of $18.1 \mathrm{~kg}$ at 12 weeks of age, when animals have a ruminal activity similar to that of an adult (San Martin 1991). When the animals are 8.5 months old, they have reached $34.7 \mathrm{~kg}$ of liveweight with a liveweight gain of $75 \mathrm{~g} \mathrm{day}^{-1}$. When the animals are 1 year old they weigh about $41.5 \mathrm{~kg}$ with a weight gain between 50 and $60 \mathrm{~g}$ day $^{-1}$. At 3 years old, they weigh about $59.4 \mathrm{~kg}$ with a weight gain of $10-20 \mathrm{~g} \mathrm{day}^{-1}$. Their weight exceeds $62 \mathrm{~kg}$ at 7 years of age. These results show that growth conditions for alpacas under extensive grazing on a Mediterranean Range are better than those for alpacas of the same age on Altiplanic environment (Bustinza 1991). Under mediterranean conditions, it is possible to wean early, with a liveweight of $18-20 \mathrm{~kg}$ and first mate one-year-olds with a minimum liveweight of $40-42 \mathrm{~kg}$. In pasture conditions similar to those in New Zealand, higher birth weights and average daily weight gains than those reported in Mediterranean grasslands can be expected (Davis et al. 1991). Although alpacas grow faster under better nutritioinal conditions, when the growth coefficient (CGRO) from the preceeding equation is compared to that of other herbivores, such as sheep, the CGRO appears relatively low (Brody 1945, reported by Standing Committce on Agriculture 1990). This indicates that alpacas grow relatively slow even under improved conditions.

\section{Fiber Production}

The annual fiber production by adult alpacas is shown in Table 3. Fiber production from males, over the 3 seasons studied, was greater than that from females. Average values ( \pm SE) were 2.36 \pm 0.08 and $1.57 \pm 0.06$ for males and females, respectively. Fleece production was lower in 1991 than in the other 2 years, probably because the time between shearing was only 320 days. Interaction between year and sex was not significant $(P=0.476)$. The fleece percentage was higher for males $(76.0 \pm 1.2 \%)$ than for females $(69.1 \pm 0.8 \%)$, and higher in 1990 than in 1991 or 1992. Year.- sex interaction was significant at $P=0.06$. Values determined for these fleece parameters are similar to those reported for these animals in altiplanic conditions (Calle 1982; Bustinza 1991), and slightly lower than those determined in New Zealand (Davis et al. 1991).

\section{Staple Length}

Variation in staple length of adult alpaca fleeces during 1991 and 1992, is shown in Figure 6. The corresponding regression equations are shown in Table 4 . Staple length shows a lineal growth, with no great seasonal and nutritional restrictions causing negative variations in the liveweight changes. Staple growth rates, measured throughout the slope of determincd regression lineal equation, are shown in Table 5 . When the Student Hypothesis Test was used to test differences between slopes of determined regression lineal equations, there were no differences between fiber growth in males and females. However, in both sexes, growth in 1991 was greater than during 1992. The average staple length of both males and females at the time of shearing was $9.8 \pm 1.0 \mathrm{~cm}$ in 1991 , and $8.4 \pm 0.6 \mathrm{~cm}$ in 1992 . These values are similar to those cited by Russel (1990) for alpacas. Therefore, the minimum fiber length required by indurstry can be obtained from annual shearing.

Table 4. Regression equations of length of staple (cm) on time (days after shearing) for female and male alpacas, during $1991-1992$

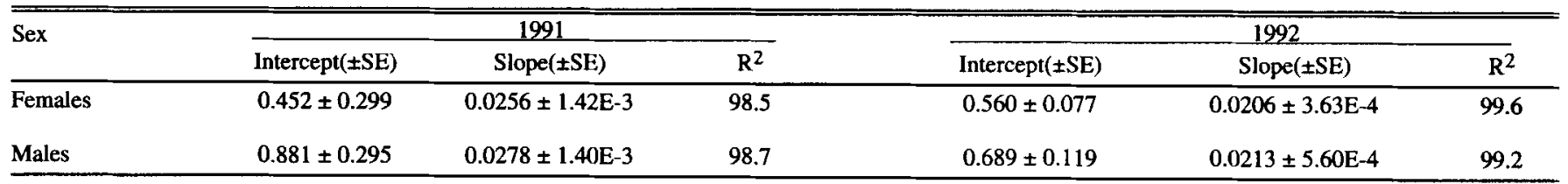


Table 5. Staple growth rates ( \pm SE) for female and male alpalcas, 1991, 1992.

\begin{tabular}{|c|c|c|}
\hline Sex & 1991 & 1992 \\
\hline Females & $0.256 \pm 0.014 \mathrm{a}^{1}$ & $0.206 \pm 0.004 \mathrm{~b}$ \\
\hline Males & $0.278 \pm 0.014 a$ & $0.213 \pm 0.006 \mathrm{~b}$ \\
\hline
\end{tabular}

${ }^{1}$ Means for sex or year followed by the same letter are not significantly different at the 5\% level.

\section{Conclusions}

Natural Mediterranean grasslands can provide alpaca maintenance requirements plus that needed for growth and fleece production. However, supplemental feeding, especially for females, should be provided from the middle of summer through the beginning of winter for maximum production. Growth is faster on Mediterranean grasslands than on the Andean High Plateau grasslands and in the Altiplanic environment. Acceptable fleece production can be obtained from annual shearing. However, more research is needed to maximize alpaca fleece production under these conditions.

\section{Literature Cited}

Bustinza, V. 1991. Mejoramiento genético, p. 113-128. In: César Novoa y Arturo Flórez (eds), Producción de rumiantes Menores: Alpacas RERUMEN. Lima, Perú.

Calle, R. 1982. Producción y mejoramiento de la alpaca. Banco Agrario del Perú. Lima. Perú.

Castellaro, G. and J. Garcia-Huidobro. 1991. Manejo de alpacas como alternativa de producción para el secano mediterráneo. Instituto de Investigaciones Agropecuarias (INIA). Informe Annual. Convenio INIA-Fundación Andes. Santiago.

Coronado, J.L., A. Corral, P. López, R. Miñano, B. Ruiz, and J. Villén. 1994. Estadística aplicada con statgraphics. Addison-Wesley Iberoamericana. Ra-Ma.

Crossley, J., L.A. Raggi, and V. Mac Niven. 1990. Constantes fisiolgicas de interés clínico de alpacas chilenas (Lama pacos Linn.) en el altiplano y zona central. Monografías de Medicina Veterinaria 12:52-58.

De Carolis G. 1987. Descripción del sistema y hábitos alimentarios de camélidos domésticos en el bofedal de Parinacota. Tesis Ing. Agr., Universidad de Chile, Facultad de Ciencias Agrarias y Forestales. Santiago.

Davis, G.H., T. Wuliji, G.H. Moore, and G.D. Bruce. 1991. Growth, reproduction and fibre production of alpacas imported from Chile, $\mathrm{p}$. 225-258. In: Proc. Of the New Zealand Society of Animal Production Vol. 51.

Fowler, M. F. 1989. Medicine and surgery of South American camelids. Ames. Iowa State University Press.

Marquardt, D.W. 1963. An algorithm for least-squares estimation of nonlinear parameters. J. of the Soc. of Indust. and Appl. Math. $11: 431-441$.

Rodríguez, D. and F. Squella. 1987. Producción y calidad estacional de distintas praderas en el secano. Instituto de Investigaciones Agropecuarias. Subestación Experimental Hindango. Area de Producción Animal. Informe Técnico 1986-1987. Santiago.

Russel, A. 1990. Camelid fibre production, pp. 38-42. In: South American Camelids. Proc. of the 1st. Conference of the British Camelids Owners' and Breeders' Association. Rowett Research Institute and Macaulay Land Use Research Institute. Aberdeen, Scotland.
San Martín, F. 1991. Nutrición y alimentación, pp.72-93. In: César Novoa y Arturo Flórez (eds), Producción de rumiantes Menores: Alpacas RERUMEN. Lima, Perú.

Santibáñez, Q.F. and M.J. Uribe. 1990. Atlas Agroclimático de Chile. Regiones sexta, séptima, octava, y novena. Laboratorio de Agroclimatología. Departamento de Ingeniería y Suelos. Universidad de Chile, Facultad de Ciencias Agrarias y Forestales. Santiago.

Soil Survey Staff. 1990. Keys to soil taxonomy, fourth edition. SMSS tech. monogr. Blacksburg, Virg.

Standing Committee on Agriculture, Ruminants Subcomittee. 1990. Feeding Standars for Australian Livestock. CSIRO, Australia.

Steel, R.G.D. and J.H. Torie. 1980. Principles and procedures of statistics. McGraw-Hill, N.Y. 